\title{
ASSESSMENT CRITERIA OF OPTIMAL SOLUTIONS FOR CREATION OF RODS WITH PIECEWISE CONSTANT CROSS-SECTIONS WITH STABILITY CONSTRAINTS OR CONSTRAINTS FOR VALUE OF THE FIRST NATURAL FREQUENCY PART 2: NUMERICAL EXAMPLES
}

\author{
Leonid S. Lyakhovich ${ }^{1}$, Pavel A. Akimov ${ }^{1,2,3,4}$, Boris A. Tukhfatullin ${ }^{1}$ \\ ${ }^{1}$ Tomsk State University of Architecture and Civil Engineering, Tomsk, RUSSIA \\ ${ }^{2}$ Russian Academy of Architecture and Building Sciences, Moscow, RUSSIA \\ ${ }^{3}$ Scientific Research Center "StaDyO", Moscow, RUSSIA \\ ${ }^{4}$ Peoples' Friendship University of Russia, Moscow, RUSSIA
}

\begin{abstract}
The special properties of optimal systems have been already identified. Besides, criteria has been formulated to assess the proximity of optimal solutions to the minimal material consumption. In particular, the criteria were created for rods with rectangular and I-beam cross-section with stability constraints or constraints for the value of the first natural frequency. These criteria can be used for optimization when the cross sections of a bar change continuously along its length. The resulting optimal solutions can be considered as an idealized object in the sense of the limit. This function of optimal design allows researcher to assess the actual design solution by the criterion of its proximity to the corresponding limit (for example, regarding material consumption). Such optimal project can also be used as a reference point in real design, for example, implementing a step-bystep process of moving away from the ideal object to the real one. At each stage, it is possible to assess the changes in the optimality index of the object in comparison with both the initial and the idealized solution. One of the variants of such a process is replacing the continuous change in the size of the cross sections of the rod along its length with piecewise constant sections. Boundaries of corresponding intervals can be selected based on an ideal feature, and cross-section dimensions can be determined by one of the optimization methods. The distinctive paper is devoted to criteria that allow researcher providing reliable assessment of the endpoint of the optimization process, and the second part of the material presented contains corresponding numerical examples, prepared in accordance with the theoretical foundations given in the first part.
\end{abstract}

Keywords: criterion, optimization, special properties, stability, frequency, critical force, buckling, eigenmode, reduced stresses, verification

\section{КРИТЕРИИ ОЦЕНКИ ОПТИМАЛЬНЫХ РЕШЕНИЙ ПРИ ФОРМИРОВАНИИ СТЕРЖНЕЙ С КУСОЧНО-ПОСТОЯННЫМИ УЧАСТКАМИ, НА КАЖДОМ ИЗ КОТОРЫХ ПОПЕРЕЧНЫЕ СЕЧЕНИЯ НЕ МЕНЯЮТСЯ, ПРИ ОГРАНИЧЕНИЯХ ПО УСТОЙЧИВОСТИ ИЛИ НА ВЕЛИЧИНУ ПЕРВОЙ СОБСТВЕННОЙ ЧАСТОТЫ ЧАСТЬ 2: ПРИМЕРЫ РАСЧЕТА}

\author{
Л.С. Ляхович ${ }^{1}$, П.А. Акимов ${ }^{1,2,3,4}$, Б.А. Тухфатуллинн $^{1}$
}

Аннотация: Ранее были выявлены особые свойства оптимальных систем и сформулированы критерии, оценивающие близость оптимальных решений к минимально материалоемкому. В частности были со- 
зданы критерии, для стержней с прямоугольным и двутавровым поперечным сечением при ограничениях по устойчивости или на величину первой частоты собственных колебаний. Эти критерии применимы при оптимизации, когда поперечные сечения стержня непрерывно изменяются по его длине. Полученные при этом оптимальные решения могут рассматриваться как идеализированный объект в смысле предельного. Эта функция оптимального проекта позволяет оценивать реальное конструкторское решение по критерию его близости к предельному (например, по материалоемкости). Такой оптимальный проект также может использоваться и как ориентир при реальном проектировании, например, реализуя поэтапный процесс отхода от идеального объекта к реальному. При этом на каждом этапе появляется возможность оценки изменения показателя оптимальности объекта по сравнению, как с начальным, так и с идеализированным решением. Одни из вариантов такого процесса состоит в замене непрерывного изменения размеров поперечных сечений стержня по его длине кусочно-постоянными участками. Границы участков могут выбираться на основе идеального объекта, а размеры поперечных сечений определяться одним из методов оптимизации. В данной статье предлагаются критерии, позволяющие надежно оценивать момент окончания процесса такой оптимизации, причем представляемая вторая часть материала публикации содержит пример расчета в соответствии с изложенными в первой части теоретическими основами.

Ключевые слова: критерий, оптимизация, особые свойства, устойчивость, частота, критическая сила, формы потери устойчивости, формы собственных колебаний, приведенные напряжения, верификация

\section{EXAMPLE 1}

Let us consider a straight cantilever rod (structure), the span of the structure of rectangular cross section is equal to $l=6 \mathrm{~m}$. Let the structure be loaded with a longitudinal force $P=300000 \mathrm{~N}$ and corresponding intensity of distributed mass is equal to $m(x)=75 \mathrm{~kg} / \mathrm{m}$. After the transition to corresponding discrete model (including 25 segments), the nodal mass is be equal to $18 \mathrm{~kg}$. Specific mass is equal to $\rho=2400 \mathrm{~kg} / \mathrm{m}^{3}$. The given value of the first circular natural frequency is equal to $\omega_{0}=20 \mathrm{~s}^{-1}$, the elastic modulus of the material is equal to $E=24000 \mathrm{MPa}$ (Figure 4a) $[8,9]$.

Since the boundary conditions in both main planes of inertia are the same, when optimizing the cross-section should be square.

Let us first consider the use of criterion (22) for evaluating optimization stages $[1-7,9,10]$ for the case when the cross sections change continuously. Optimization is performed by random search. For the initial approximation, a rod of constant cross-sectional length is taken with the ratio $b_{1}^{0}[i] / b_{2}^{0}[i]=1 / 1$. The values of the desired parameters at the first exit to the boundary of the region of feasible solutions turned out to be equal to $b_{1}^{0}[i]=b_{2}^{0}[i]=0.3039 \mathrm{~m}$. In this case, the objective function is equal to
$V_{0}=0.5543 \mathrm{~m}^{3}$. The results of the three stages of the search are summarized in Table 1. The results of the first stage are obtained after $n=1000$ attempts of the random search method, the second after $n=1500$ attempts, the third when $n \succ 2000$. The second column of Table 1 shows the values of the cross-sectional dimensions at the first exit to the boundary of the region of feasible solutions $b_{1}^{0}[i]=b_{2}^{0}[i]=0.3039 \mathrm{~m}$. The penultimate row of the table shows the values of the objective function $V_{0}$ at each stage, and the last one shows its percentage reduction compared to the initial one. Columns 3, 5, 7 show the sizes of the cross sections obtained at each stage, and in columns $4,6,8$ the values of criterion (22). The table shows that the values of the objective function in comparison with the first stage are almost not reduced. The differences concern only the fourth significant digit. The difference in the size of some sections concerns the third significant digits. However, the values of criterion (22) in the first and second stages indicate that the optimization process is not completed.

The values of criterion (22) at the third stage are close to unity, which allows researcher to confidently make a decision about stopping the optimization process at this stage. 
Assessment Criteria of Optimal Solutions for Creation of Rods With Piecewise Constant Cross-Sections With Stability Constraints or Constraints for Value of the First Natural Frequency. Part 2: Numerical Examples

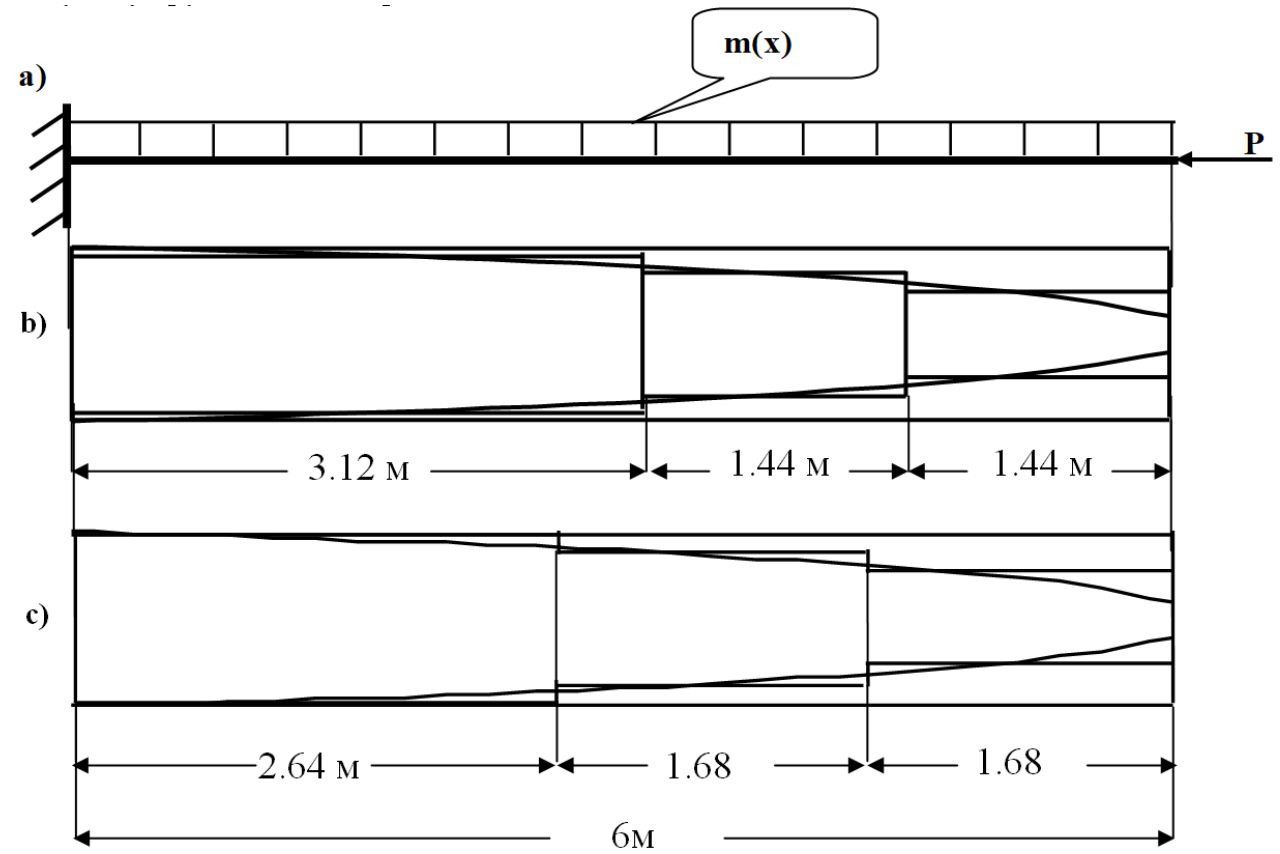

Figure 4. About the first example.

Table 1. Information about solution of the first example.

\begin{tabular}{|c|c|c|c|c|c|c|c|}
\hline \multirow{3}{*}{$\begin{array}{c}1 \\
\text { No. } 1\end{array}$} & \multicolumn{7}{|c|}{ Optimization stages } \\
\hline & \multirow{2}{*}{$\frac{\text { Initial }}{b_{1}^{0}[i], m}$} & \multicolumn{2}{|c|}{ The first $n=1000$} & \multicolumn{2}{|c|}{ The second $n=1500$} & \multicolumn{2}{|c|}{ The third $n \succ 2000$} \\
\hline & & $b_{1}[i], m$ & $\sigma_{1 \omega}^{2}[i]$ & $b_{1}[i], m$ & $\sigma_{1 \omega}^{2}[i]$ & $b_{1}[i], m$ & $\sigma_{1 \omega}^{2}[i]$ \\
\hline 1 & 0.3039 & 0.3072 & 0.8359 & 0.3065 & 0.8414 & 0.3076 & 0.9997 \\
\hline 2 & 0.3039 & 0.3057 & 0.7926 & 0.3050 & 0.8019 & 0.3038 & 0.9996 \\
\hline 3 & 0.3039 & 0.2983 & 0.8491 & 0.2986 & 0.8513 & 0.2998 & 0.9997 \\
\hline 4 & 0.3039 & 0.2995 & 0.7622 & 0.2973 & 0.8012 & 0.2956 & 0.9996 \\
\hline 5 & 0.3039 & 0.2917 & 0.8206 & 0.2886 & 0.8722 & 0.2912 & 0.9996 \\
\hline 6 & 0.3039 & 0.2865 & 0.8249 & 0.2883 & 0.7992 & 0.2865 & 0.9996 \\
\hline 7 & 0.3039 & 0.2815 & 0.8224 & 0.2867 & 0.7404 & 0.2815 & 0.9995 \\
\hline 8 & 0.3039 & 0.2754 & 0.8447 & 0.2761 & 0.8280 & 0.2762 & 0.9997 \\
\hline 9 & 0.3039 & 0.2723 & 0.7922 & 0.2693 & 0.8456 & 0.2706 & 0.9996 \\
\hline 10 & 0.3039 & 0.2653 & 0.8185 & 0.2639 & 0.8354 & 0.2646 & 0.9995 \\
\hline 11 & 0.3039 & 0.2599 & 0.7917 & 0.2562 & 0.8666 & 0.2582 & 0.9999 \\
\hline 12 & 0.3039 & 0.2529 & 0.7966 & 0.2515 & 0.8218 & 0.2515 & 0.9997 \\
\hline 13 & 0.3039 & 0.2425 & 0.8649 & 0.2403 & 0.9168 & 0.2442 & 0.9998 \\
\hline 14 & 0.3039 & 0.2383 & 0.7819 & 0.2390 & 0.7693 & 0.2364 & 0.9998 \\
\hline 15 & 0.3039 & 0.2238 & 0.9477 & 0.2265 & 0.8634 & 0.2281 & 0.9996 \\
\hline 16 & 0.3039 & 0.2217 & 0.7673 & 0.2196 & 0.8155 & 0.2193 & 0.9998 \\
\hline 17 & 0.3039 & 0.2071 & 0.9186 & 0.2112 & 0.7779 & 0.2097 & 0.9997 \\
\hline 18 & 0.3039 & 0.1972 & 0.9097 & 0.2022 & 0.7275 & 0.1995 & 0.9996 \\
\hline 19 & 0.3039 & 0.1885 & 0.8326 & 0.1898 & 0.7655 & 0.1885 & 0.9997 \\
\hline 20 & 0.3039 & 0.1739 & 0.9330 & 0.1717 & 1.0000 & 0.1765 & 1.0000 \\
\hline 21 & 0.3039 & 0.1598 & 1.0000 & 0.1636 & 0.7799 & 0.1634 & 0.9996 \\
\hline 22 & 0.3039 & 0.1486 & 0.8121 & 0.1481 & 0.8078 & 0.1486 & 0.9994 \\
\hline 23 & 0.3039 & 0.1328 & 0.6891 & 0.1320 & 0.7145 & 0.1315 & 0.9993 \\
\hline 24 & 0.3039 & 0.1181 & 0.1642 & 0.1134 & 0.4544 & 0.1099 & 0.9988 \\
\hline 25 & 0.3039 & 0.0964 & -0.6147 & 0.0889 & -0.3683 & 0.0761 & 0.9994 \\
\hline$V_{0}, m^{3}$ & 0.5543 & 0.3397 & & 0.3391 & & 0.3384 & \\
\hline$\%$ & 0 & $38.71 \%$ & & $38.83 \%$ & & $38.95 \%$ & \\
\hline
\end{tabular}


Table 2. Information about variants of solution of the first example.

\begin{tabular}{|c|c|c|c|c|c|c|}
\hline \multirow{2}{*}{1} & \multicolumn{3}{|c|}{ Вариант 1 } & \multicolumn{3}{c|}{ Вариант 2 } \\
\cline { 2 - 7 } & 2 & 3 & 4 & 5 & 6 & 7 \\
\hline No. & $b_{1 k}[i], m$ & $\sigma_{1 \omega}^{2}[i]$ & $S_{1}[i]$ & $b_{1}[i], m$ & $\sigma_{1 \omega}^{2}[i]$ & $S_{1}[i]$ \\
\hline 1 & 0.2901 & 0.4123 & 0.9999 & 0.2956 & 0.3627 & 0.9999 \\
\hline 2 & 0.2901 & 0.3811 & 0.9999 & 0.2956 & 0.3357 & 0.9999 \\
\hline 3 & 0.2901 & 0.3502 & 0.9999 & 0.2956 & 0.3090 & 0.9999 \\
\hline 4 & 0.2901 & 0.3198 & 0.9999 & 0.2956 & 0.2827 & 0.9999 \\
\hline 5 & 0.2901 & 0.2900 & 0.9999 & 0.2956 & 0.2570 & 0.9999 \\
\hline 6 & 0.2901 & 0.2609 & 0.9999 & 0.2956 & 0.2319 & 0.9999 \\
\hline 7 & 0.2901 & 0.2327 & 0.9999 & 0.2956 & 0.2075 & 0.9999 \\
\hline 8 & 0.2901 & 0.2053 & 0.9999 & 0.2956 & 0.1838 & 0.9999 \\
\hline 9 & 0.2901 & 0.1790 & 0.9999 & 0.2956 & 0.1610 & 0.9999 \\
\hline 10 & 0.2901 & 0.1536 & 0.9999 & 0.2956 & 0.1390 & 0.9999 \\
\hline 11 & 0.2901 & 0.1293 & 0.9999 & 0.2956 & 0.1179 & 0.9999 \\
\hline 12 & 0.2901 & 0.1060 & 0.9999 & 0.2346 & 0.4226 & 0.9998 \\
\hline 13 & 0.2901 & 0.0837 & 0.9999 & 0.2346 & 0.3539 & 0.9998 \\
\hline 14 & 0.2190 & 0.4363 & 1.0000 & 0.2346 & 0.2888 & 0.9998 \\
\hline 15 & 0.2190 & 0.3496 & 1.0000 & 0.2346 & 0.2275 & 0.9998 \\
\hline 16 & 0.2190 & 0.2685 & 1.0000 & 0.2346 & 0.1702 & 0.9998 \\
\hline 17 & 0.2190 & 0.1934 & 1.0000 & 0.2346 & 0.1167 & 0.9998 \\
\hline 18 & 0.2190 & 0.1242 & 1.0000 & 0.2346 & 0.0670 & 0.9998 \\
\hline 19 & 0.2190 & 0.0609 & 1.0000 & 0.1570 & 1.0000 & 1.0000 \\
\hline 20 & 0.1474 & 1.0000 & 0.9998 & 0.1570 & 0.6696 & 1.0000 \\
\hline 21 & 0.1474 & 0.6081 & 0.9998 & 0.1570 & 0.3794 & 1.0000 \\
\hline 22 & 0.1474 & 0.2761 & 0.9998 & 0.1570 & 0.1370 & 1.0000 \\
\hline 23 & 0.1474 & 0.0145 & 0.9998 & 0.1570 & -0.0541 & 1.0000 \\
\hline 24 & 0.1474 & -0.1737 & 0.9998 & 0.1570 & -0.1948 & 1.0000 \\
\hline 25 & 0.1474 & -0.2925 & 0.9998 & 0.1570 & -0.2900 & 1.0000 \\
\hline$V_{0}, m^{3}$ & 0.3630 & & & 0.3645 & & \\
\hline$\%$ & $34.52 \%$ & & & $34.24 \%$ & & \\
\hline & & & & & & \\
\hline
\end{tabular}

The values of criterion (22) at the third stage are close to unity, which allows researcher to confidently make a decision about stopping the optimization process at this stage.

The results obtained determine the core of minimal material consumption. The shape of the cross-sectional dimensions of this $\operatorname{rod}\left(b_{1}[i]\right)$ is shown in Figures $3 b$ and $3 c$.

If technological requirements do not allow such a law to change the size of cross sections, but allow a piecewise-constant change in cross sections, then the choice of the boundaries of such sections is determined not only by technological requirements knowledge, but also the desire to come closer to a minimally material-intensive solution. Suppose that technological requirements are allowed for the design of the rod from three sections, in each of which the dimensions of the cross sections do not change. Suppose that additional restrictions are also imposed on the length of sections, for example, such as

$$
\begin{gathered}
2.8 m \leq l_{u}[2] \leq 3.8 m ; \\
l_{u}[1]=l_{u}[3]=\left(l-l_{u}[2]\right) / 2 .
\end{gathered}
$$

Let us consider two options for the boundaries of the segments. Variants of the boundaries of the segments and the corresponding segment sizes obtained by optimization are shown in Figures $4 b$ and $4 c$ and are shown in Table 2.

Columns 2 and 5 show the cross-sectional dimensions $b_{1 k}[i]=b_{2 k}[i]$ of the respective options. Columns 3 and 6 show the values of criterion (28), and columns 4 and 7 of criterion (24). 


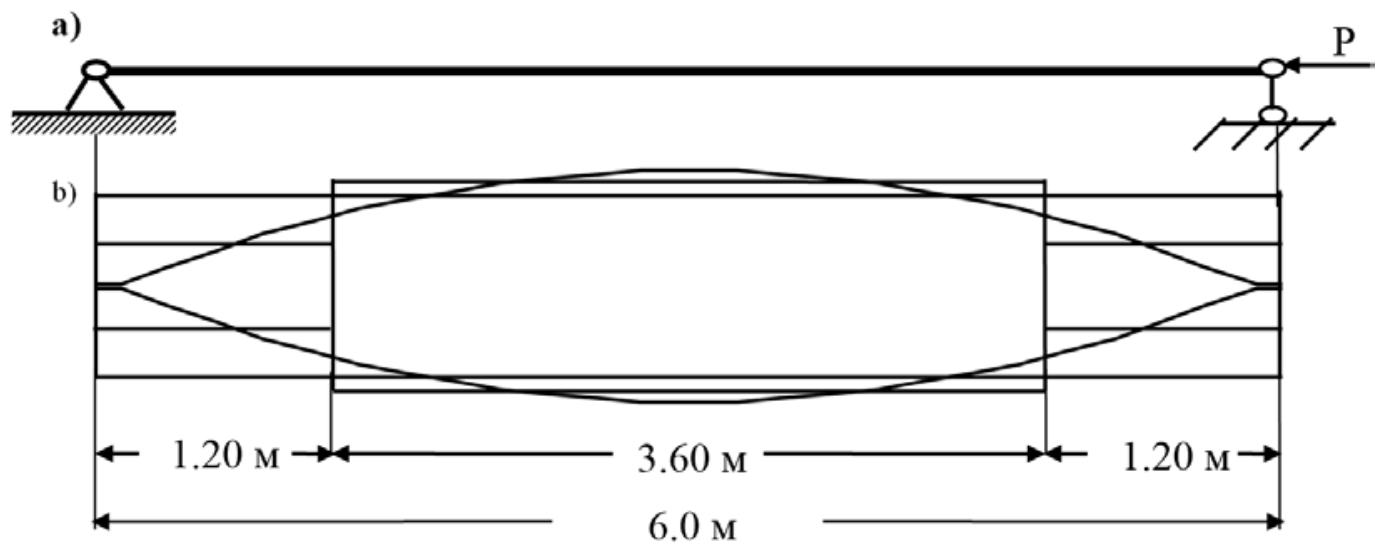

Figure 5. About the second example.

Both criteria are given because, as noted above, in each piecewise constant segment, criterion (24) is implemented as the average value of criterion (28) per unit length of the segment.

The values of criterion (24) in both cases turned out to be close to unity, which indicated the possibility of completing the optimization processes.

The objective function of the minimum material-intensive solution (Table 1, column 7) is equal to $V_{0}=0.3384 \mathrm{~m}^{3}$, which is $38.95 \%$ less than the original version, which has $V_{0}=0.5543 \mathrm{~m}^{3}$ (Table 1, column 2). In the first version of the boundaries of piecewise constant resizing, the objective function is equal to $V_{0}=0.3630 \mathrm{~m}^{3}$, which is $34.52 \%$ less than the original version. In the second version, the objective function is equal to $V_{0}=0.3645 \mathrm{~m}^{3}$, which is $34.24 \%$ less than the original version. Thus, the first option for choosing the boundaries of the plots is less material-intensive. Note that the minimally material-intensive option contributed to the selection of the boundaries of the segments, allowing researcher to choose options that are closest to it.

\section{EXAMPLE 2}

Let us consider an example of the use of criterion (50) for the case when stability constraints are introduced.
Particularly let us consider a straight-line simply supported rod of an I-section with a span $l=6 m$ loaded with longitudinal force $P=9000000 H$ (Figure 5a). The modulus of elasticity of the material is equal to $E=206000 \mathrm{MPa}$. I-section height is equal to $b_{1}=0.29 \mathrm{M}$, wall thickness is equal to $\delta_{\text {st }}=0.009_{\mathcal{M}}$, shelves thickness is equal to $\delta_{\mathrm{p}}=0.014 \mathrm{M}$.

It is required to determine the shape of the shelve of the I-beam in such a way that the critical force would not be greater than the acting force, and the volume of material of the shelf would be minimal.

The stability constraint can be written as

$$
P=P_{c r}
$$

Besides, the objective function has the form (37). We will carry out optimization by a random search method based on a discrete model from 25 segments.

Let's consider three versions. Within the initial version a shelf of constant section length is taken. The values of its sizes are determined at the first exit to the boundary of the region of feasible solutions. They turned out to be equal to $b_{2}^{0}[i]=0.2737 \mathcal{M}$. In this case, the objective function is equal to $V_{0}=0.0460 \mathrm{M}^{3}$. The results of this version are presented in the second column of Table 3 and in Figure $5 b$. 
Table 3. Information about variants of solution of the second example.

\begin{tabular}{|c|c|c|c|c|c|c|}
\hline No. & $b_{2}^{0}[i], M$ & $b_{2 k}[i], m$ & $\sigma_{1 \omega}^{2}[i]$ & $b_{2 k}[i], m$ & $\sigma_{1 \omega}^{2}[i]$ & $S_{1}[i]$ \\
\hline 1 & 2 & 3 & 4 & 5 & 6 & 7 \\
\hline 1 & 0.2737 & 0.009 & 0.7308 & 0.1233 & 0.0153 & 1.0000 \\
\hline 2 & 0.2737 & 0.0581 & 0.9994 & 0.1233 & 0.1351 & 1.0000 \\
\hline 3 & 0.2737 & 0.1075 & 1.0000 & 0.1233 & 0.3596 & 1.0000 \\
\hline 4 & 0.2737 & 0.1524 & 0.9986 & 0.1233 & 0.6605 & 1.0000 \\
\hline 5 & 0.2737 & 0.1926 & 0.9976 & 0.1233 & 1.0000 & 1.0000 \\
\hline 6 & 0.2737 & 0.2277 & 0.9999 & 0.3139 & 0.2564 & 0.9992 \\
\hline 7 & 0.2737 & 0.2584 & 0.9997 & 0.3139 & 0.3220 & 0.9992 \\
\hline 8 & 0.2737 & 0.2843 & 0.9994 & 0.3139 & 0.3852 & 0.9992 \\
\hline 9 & 0.2737 & 0.3057 & 0.9985 & 0.3139 & 0.4426 & 0.9992 \\
\hline 10 & 0.2737 & 0.3220 & 0.9997 & 0.3139 & 0.4908 & 0.9992 \\
\hline 11 & 0.2737 & 0.3341 & 0.9976 & 0.3139 & 0.5274 & 0.9992 \\
\hline 12 & 0.2737 & 0.3412 & 0.9975 & 0.3139 & 0.5501 & 0.9992 \\
\hline 13 & 0.2737 & 0.3435 & 0.9979 & 0.3139 & 0.5578 & 0.9992 \\
\hline 14 & 0.2737 & 0.3412 & 0.9975 & 0.3139 & 0.5501 & 0.9992 \\
\hline 15 & 0.2737 & 0.3341 & 0.9976 & 0.3139 & 0.5274 & 0.9992 \\
\hline 16 & 0.2737 & 0.3220 & 0.9997 & 0.3139 & 0.4908 & 0.9992 \\
\hline 17 & 0.2737 & 0.3057 & 0.9985 & 0.3139 & 0.4426 & 0.9992 \\
\hline 18 & 0.2737 & 0.2843 & 0.9994 & 0.3139 & 0.3852 & 0.9992 \\
\hline 19 & 0.2737 & 0.2584 & 0.9997 & 0.3139 & 0.3220 & 0.9992 \\
\hline 20 & 0.2737 & 0.2277 & 0.9999 & 0.3139 & 0.2564 & 0.9992 \\
\hline 21 & 0.2737 & 0.1926 & 0.9976 & 0.1233 & 1.0000 & 1.0000 \\
\hline 22 & 0.2737 & 0.1524 & 0.9986 & 0.1233 & 0.6605 & 1.0000 \\
\hline 23 & 0.2737 & 0.1075 & 1.0000 & 0.1233 & 0.3596 & 1.0000 \\
\hline 24 & 0.2737 & 0.0581 & 0.9994 & 0.1233 & 0.1351 & 1.0000 \\
\hline 25 & 0.2737 & 0.009 & 0.7308 & 0.1233 & 0.0153 & 1.0000 \\
\hline$V_{0}, m$ & 0.0460 & 0.0372 & & 0.0399 & & \\
\hline$\%$ & 0 & $19.20 \%$ & & $13.18 \%$ & & \\
\hline & & & & & & \\
\hline
\end{tabular}

In the second version, a continuous change in the size of the width of the shelf is considered. Here, the criterion for stopping the optimization process is the proximity of the normalized value of criterion (32) to unity. In sections 1 and 25, the criterion is significantly different from unity, which is explained by the achievement of the width of the shelf the size of the wall thickness and the optimization process stopping in these sections. The results of this option are shown in columns 3 and 4 of Table 3 and in Figure $5 b$. The objective function in this version is equal to $V_{0}=0.0372 \mathcal{M}^{3}$, which is $19.20 \%$ less than the original version.

In the third version, a piecewise constant change in the width of the shelf is considered. As noted above, the choice of the boundaries of segments where sizes do not change is determined by both technological requirements and the desire to get as close as possible to a minimally materialintensive solution, in this example, a solution according to the second version. Let us assume that the technological requirements allow the design of the rod from three sections. Since the purpose of the example is to illustrate the criterion (50), then, given the limitation of the size of the paper, we consider only one option for choosing the boundaries of the segments (Figure $5)$.

The optimization results of this version are shown in columns 5, 6, 7 of Table 3 and in Figure $5 b$. The values of criterion (50) (column 7 of Table 3) in all sections are close to unity, which allows the optimization process to be stopped.

The goal function in this version is equal to $V_{0}=0.0399 \mathcal{M}^{3}$, which is $13.18 \%$ less than the original version. 


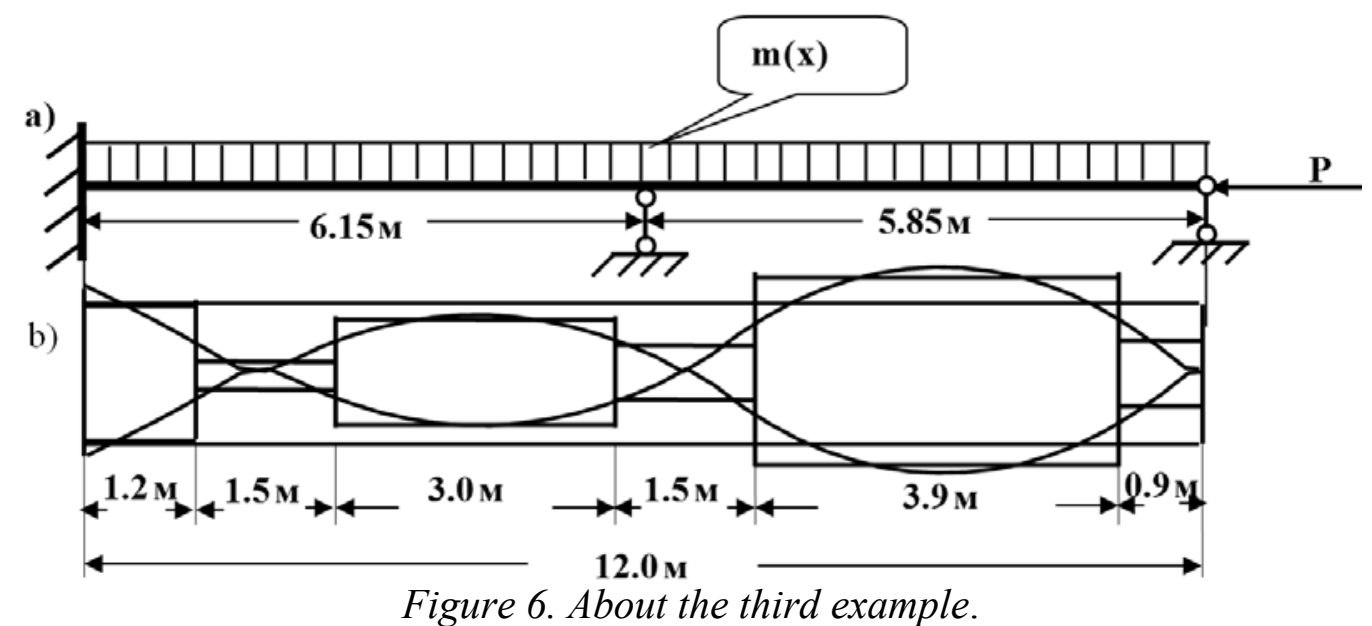

\section{EXAMPLE 3}

Let us consider an example illustrating the application of criteria for multi-span rods.

In particular, let us consider a two-span rod of an I-section, loaded with longitudinal force $P=5000000 H$ and bearing a distributed mass $m(x)=200 \mathrm{~kg} / m$ (Figure $6 a)$.

The modulus of elasticity of the material is equal to $E=206000 M \Pi a$, specific gravity is equal to $\rho=7850 \mathrm{~kg} / \mathrm{m}^{3}$. I-section height is equal to $b_{1}=0.29 \mathrm{M}$, wall thickness is equal to $\delta_{\text {st }}=0.009_{M}$, shelves thickness is equal to $\delta_{\mathrm{p}}=0.014 \mathrm{M}$.

It is required to determine the shape of the shelve of the I-beam in such a way that the first frequency of natural vibrations would be no more than a given value $\omega_{0}=90 \mathrm{sec}^{-1}$, and the volume of material of the shelf would be minimal. Optimization can be done by a random search method based on a discrete model from 40 segments (sections).

Let us consider three versions. For the initial version, a shelf of constant section length is taken. The values of its sizes are determined at the first exit to the boundary of the region of feasible solutions. They turned out to be equal $b_{2}^{0}[i]=0.2934 \mu$. In this case, the objective function is equal to. The results of this option are presented in the second column of Table 4 and in Figure $6 b$.

In the second version, a continuous change in the size of the width of the shelf is considered. Here, the criterion for stopping the optimization process is the proximity of the normalized value of criterion (32) to unity. In sections 7 and 22, the criterion differs significantly from unity, which is explained by the achievement of the width of the shelf size close to the wall thickness and the optimization process stopping in these sections. The results of this option are shown in columns 3 and 4 of table 4 and in Figure $6 b$. The objective function in this version is equal to $V_{0}=0.0758 \mathrm{~m}^{3}$, which is $23.10 \%$ less than the original version.

In the third version, a piecewise constant change in the width of the shelf is considered. As noted above, the choice of the boundaries of areas where sizes do not change is determined by both technological requirements and the desire to get as close as possible to a minimally materialintensive solution. Given the limitation of the volume of the paper, we consider only one option for choosing the boundaries of the segments (Figure 6).

The optimization results of this option are shown in columns 5, 6, 7 of Table 4 and in Figure $6 b$. The values of criterion (50) (column 7 of Table 4) in all sections are close to unity, which allows the optimization process to be stopped. 
Table 4. Information about variants of solution of the third example.

\begin{tabular}{|c|c|c|c|c|c|c|}
\hline No. & $b_{1}^{0}[i], m$ & $b_{1}[i], m$ & $\sigma_{1 \omega}^{2}[i]$ & $b_{1 k}[i], M$ & $\sigma_{1 \omega}^{2}[i]$ & $S_{1}[i]$ \\
\hline 1 & 2 & 3 & 4 & 5 & 6 & 7 \\
\hline 1 & 0.2934 & 0.3400 & 0.9962 & 0.2772 & 0.6888 & 0.9994 \\
\hline 2 & 0.2934 & 0.2842 & 0.9961 & 0.2772 & 0.4922 & 0.9994 \\
\hline 3 & 0.2934 & 0.2243 & 0.9974 & 0.2772 & 0.3177 & 0.9994 \\
\hline 4 & 0.2934 & 0.1610 & 0.9948 & 0.2772 & 0.1743 & 0.9994 \\
\hline 5 & 0.2934 & 0.0939 & 0.9982 & 0.0706 & 0.7387 & 0.9994 \\
\hline 6 & 0.2934 & 0.0254 & 0.9766 & 0.0706 & 0.1250 & 0.9994 \\
\hline 7 & 0.2934 & 0.0099 & 0.2779 & 0.0706 & -0.0121 & 0.9994 \\
\hline 8 & 0.2934 & 0.0574 & 1.0000 & 0.0706 & 0.2994 & 0.9994 \\
\hline 9 & 0.2934 & 0.1116 & 0.9900 & 0.0706 & 0.9401 & 0.9994 \\
\hline 10 & 0.2934 & 0.1556 & 0.9955 & 0.2199 & 0.2063 & 0.9997 \\
\hline 11 & 0.2934 & 0.1906 & 0.9971 & 0.2199 & 0.3243 & 0.9997 \\
\hline 12 & 0.2934 & 0.2168 & 0.9976 & 0.2199 & 0.4317 & 0.9997 \\
\hline 13 & 0.2934 & 0.2350 & 0.9930 & 0.2199 & 0.5129 & 0.9997 \\
\hline 14 & 0.2934 & 0.2439 & 0.9950 & 0.2199 & 0.5574 & 0.9997 \\
\hline 15 & 0.2934 & 0.2451 & 0.9914 & 0.2199 & 0.5605 & 0.9997 \\
\hline 16 & 0.2934 & 0.2370 & 0.9954 & 0.2199 & 0.5232 & 0.9997 \\
\hline 17 & 0.2934 & 0.2206 & 0.9963 & 0.2199 & 0.4523 & 0.9997 \\
\hline 18 & 0.2934 & 0.1958 & 0.9960 & 0.2199 & 0.3589 & 0.9997 \\
\hline 19 & 0.2934 & 0.1625 & 0.9945 & 0.2199 & 0.2561 & 0.9997 \\
\hline 20 & 0.2934 & 0.1206 & 0.9986 & 0.1046 & 0.5722 & 0.9989 \\
\hline 21 & 0.2934 & 0.0722 & 0.9970 & 0.1046 & 0.2569 & 0.9989 \\
\hline 22 & 0.2934 & 0.009 & 0.0091 & 0.1046 & -0.0045 & 0.9989 \\
\hline 23 & 0.2934 & 0.0778 & 0.9993 & 0.1046 & 0.2657 & 0.9989 \\
\hline 24 & 0.2934 & 0.1657 & 0.9938 & 0.1046 & 1.0000 & 0.9989 \\
\hline 25 & 0.2934 & 0.2407 & 0.9946 & 0.3908 & 0.1419 & 0.9998 \\
\hline 26 & 0.2934 & 0.3030 & 0.9947 & 0.3908 & 0.2415 & 0.9998 \\
\hline 27 & 0.2934 & 0.3528 & 0.9972 & 0.3908 & 0.3473 & 0.9998 \\
\hline 28 & 0.2934 & 0.3916 & 0.9955 & 0.3908 & 0.4472 & 0.9998 \\
\hline 29 & 0.2934 & 0.4192 & 0.9959 & 0.3908 & 0.5300 & 0.9998 \\
\hline 30 & 0.2934 & 0.4364 & 0.9962 & 0.3908 & 0.5868 & 0.9998 \\
\hline 31 & 0.2934 & 0.4436 & 0.9962 & 0.3908 & 0.6115 & 0.9998 \\
\hline 32 & 0.2934 & 0.4410 & 0.9962 & 0.3908 & 0.6017 & 0.9998 \\
\hline 33 & 0.2934 & 0.4281 & 0.9974 & 0.3908 & 0.5588 & 0.9998 \\
\hline 34 & 0.2934 & 0.4057 & 0.9943 & 0.3908 & 0.4876 & 0.9998 \\
\hline 35 & 0.2934 & 0.3714 & 0.9967 & 0.3908 & 0.3961 & 0.9998 \\
\hline 36 & 0.2934 & 0.3264 & 0.9945 & 0.3908 & 0.2946 & 0.9998 \\
\hline 37 & 0.2934 & 0.2686 & 0.9960 & 0.3908 & 0.1942 & 0.9998 \\
\hline 38 & 0.2934 & 0.1987 & 0.9944 & 0.1365 & 0.8821 & 1.0000 \\
\hline 39 & 0.2934 & 0.1163 & 0.9988 & 0.1365 & 0.3351 & 1.0000 \\
\hline 40 & 0.2934 & 0.0250 & 0.9633 & 0.1365 & 0.0382 & 1.0000 \\
\hline$V_{0}, m^{3}$ & 0.0986 & 0.0758 & & 0.0813 & & \\
\hline$\%$ & 0 & $23.10 \%$ & & $17.57 \%$ & & \\
\hline
\end{tabular}

The goal function in this version is equal to $V_{0}=0.0813 \mathrm{M}^{3}$, which is $17.57 \%$ less than the original version.

\section{REFERENCES}

1. Lagrange J.-L. Sur la figure des collonnes. // Mescellanea Taurinensia, 1770-1773, Volume 5, pp. 123. 
2. Clausen T. Uber die form architektonischer Säulen. // Bull. cl. physico-raath. Acad. St.Petersburg, 1851, Volume 9, pp. 371-380.

3. Nikolai E.L. Zadacha Lagranzha o naivygodneishem ochertanii kolonny [The Lagrange problem of the best shape of the column]. // Bulletin of the St. Petersburg Polytechnic Institute, 1907, No. 8 (in Russian).

4. Lyakhovich L.S., Akimov P.A., Tukhfatullin B.A. O zadachakh poiska minimuma i maksimuma $\mathrm{v}$ stroitel'noi mekhanike [About hill-climbing problems in structural mechanics]. // International Journal for Computational Civil and Structural Engineering, 2017, Volume 13, Issue 2, pp. 103-124 (in Russian).

5. Lyakhovich L.S., Malinovsky A.P., Tukhfatullin B.A. Criteria for Optimal Strengthening of Bar Flange with I-type Cross-section with Stability Constraints on the Value of the First Natural Frequency. // Procedia Engineering, 2016. Volume 153, pp. 427-433.

6. Lyakhovich L.S. Osobye svoistva optimal'nykh sistem i osnovnye napravleniya ikh realizatsii $\mathrm{v}$ metodakh rascheta sooruzhenii [The special properties of optimal systems and the main directions of their implementation in the methods of calculation of structures]. Tomsk, Tomsk State University of Architecture and Building, 2009, 372 pages (in Russian).

7. Lyakhovich L.S., Perelmuter A.V. Nekotorye voprosy optimal'nogo proektirovaniya stroitel'nykh konstruktsii [Some problems of building constructions optimal projecting]. // International Journal for Computational Civil and Structural Engineering, 2014, Volume 10, Issue 2, pp. 1423 (in Russian).

8. Aslami M., Akimov P.A. Analytical solution for beams with multipoint boundary conditions on two-parameter elastic foundations. // Archives of Civil and Mechanical Engineering, 2016, Volume 16, Issue 4, pp. 668-677.
9. Ludeker J.K., Kriegesmann B. Fail-safe optimization of beam structures. // Journal of Computational Design and Engineering, 2019, Volume 6, Issue 3, pp. 260-268.

10. Quinteiro G.F. Beam optimization: improving methodology. // Annals of Nuclear Energy, 2004, Volume 31, Issue 4, pp. 399411.

\section{СПИСОК ПУБЛИКАЦИЙ}

1. Lagrange J.-L. Sur la figure des collonnes. // Mescellanea Taurinensia, 1770-1773, Volume 5, pp. 123.

2. Clausen T. Uber die form architektonischer Säulen. // Bull. cl. physico-raath. Acad. St.Petersburg, 1851, Volume 9, pp. 371-380.

3. Николаи Е.Л. Задача Лагранжа о наивыгоднейшем очертании колонны. // Известия Санкт-Петербургского политехнического института. 1907. №8.

4. Ляхович Л.С., Акимов П.А., Тухфатуллин Б.А. О задачах поиска минимума и максимума в строительной механике. // International Journal for Computational Civil and Structural Engineering, 2017, Volume 13, Issue 2, pp. 103-124.

5. Lyakhovich L.S., Malinovsky A.P., Tukhfatullin B.A. Criteria for Optimal Strengthening of Bar Flange with I-type Cross-section with Stability Constraints on the Value of the First Natural Frequency. // Procedia Engineering, 2016. Volume 153, pp. 427-433.

6. Ляхович Л.С. Особые свойства оптимальных систем и основные направления их реализации в методах расчета сооружений. - Томск: Издательство Томского государственного архитектурностроительного университета, 2009. - 372 с.

7. Ляхович Л.С., Перельмутер А.В. Некоторые вопросы оптимального проектирования строительных конструкций. // International Journal for Computational Civil and Structural Engineering, 2014, Volume 10, Issue 2, pp. 14-23. 
8. Aslami M., Akimov P.A. Analytical solution for beams with multipoint boundary conditions on two-parameter elastic foundations. // Archives of Civil and Mechanical Engineering, 2016, Volume 16, Issue 4, pp. 668-677.

9. Ludeker J.K., Kriegesmann B. Fail-safe optimization of beam structures. // Journal of Computational Design and Engineering, 2019, Volume 6, Issue 3, pp. 260-268.

10. Quinteiro G.F. Beam optimization: improving methodology. // Annals of Nuclear Energy, 2004, Volume 31, Issue 4, pp. 399411.

Ляхович Леонид Семенович, академик Российской академии архитектуры и строительных наук (PA$\mathrm{ACH}$ ), профессор, доктор технических наук, профессор кафедры строительной механики, Томский государственный архитектурно-строительный университет; 634003, Россия, г. Томск, Соляная пл. 2;

E-mail: 1ls@tsuab.ru

Акимов Павел Алексеевич, академик Российской академии архитектуры и строительных наук (РАACH), профессор, доктор технических наук; главный ученый секретарь Российской академии архитектуры и строительных наук; заместитель генерального директора по науке ЗАО «Научно-исследовательский центр СтаДиО»; профессор Департамента архитектуры и строительства Российского университета дружбы народов; профессор кафедры строительной механики Томского государственного архитектурно-строительного университета; 107031, г. Москва, ул. Большая Дмитровка, д. 24, стр. 1; тел. +7(495) 625-71-63;

факс+7 (495) 650-27-31; Email: akimov@raasn.ru, pavel.akimov@gmail.com.

Тухфатуллин Борис Ахатович, доцент, кандидат технических наук, доцент кафедры строительной механики, Томский государственный архитектурностроительный университет; 634003, Россия, г. Томск, Соляная пл. 2; e-mail: bat9203@gmail.com.

Leonid S. Lyakhovich, Full Member of the Russian Academy of Architecture and Construction Sciences (RAACS), Professor, Dr.Sc., Head of Department of Structural Mechanics, Tomsk State University of Architecture and Building; 634003, Russia, Tomsk, Solyanaya St., 2; e-mail: 1ls@tsuab.ru
Pavel A. Akimov, Full Member of the Russian Academy of Architecture and Construction Sciences (RAACS), Professor, Dr.Sc.; Executive Scientific Secretary of Russian Academy of Architecture and Construction Sciences; Vice-Director for Science Activities, Scientific Research Center "StaDyO"; Professor of Department of Architecture and Construction, Peoples' Friendship University of Russia; Professor of Department of Structural Mechanics, Tomsk State University of Architecture and Building; 24, Ul. Bolshaya Dmitrovka, 107031, Moscow, Russia; phone +7(495) 625-71-63; fax: +7 (495) 650-27-31; E-mail:akimov@raasn.ru,pavel.akimov@gmail.com.

Boris A. Tukhfatullin, Associate Professor, Ph.D, Associate Professor of Department of Structural Mechanics, Tomsk State University of Architecture and Building; 634003, Russia, Tomsk, Solyanaya St., 2;

E-mail: bat9203@gmail.com. 